\title{
精神薄弱児における発見型授業と説明型授業 との比較研究
}

\author{
田口則良*
}

\section{問題}

精神薄弱児が生活場面で遭遇する課題は一般児童と変 わるものではない。しかし, 従来の精神薄弱教育では 「抽象能力や転移能力が劣るので, 断片的知識の集積に とどまりやすい」といら特徽から実質陶治に重点が扔か れた指導内容と形態が採用されており，実際生活に即し た具体的内容が将来の生活で役立つことを意図して指導 がなされている。即ち, 学校生活と将来の家庭生活・社 会生活とを同次元に位置づけ，学校生活で習得された内 容がそのまま将来の生活でも役立つという一元構造とし てとらえられている。近代社会は近き将来の生活さえ, 予見できないほど目まぐるしく変遷, 伸展しており, 現 実の生活と将来の生活とは恒常的生活場面としてとらえ られにくい。従って, これらの実態に対処していくため には将来の生活を予見した上での指導内容が構成され, それが十分に役立つようになる方法で教育がなされなけ ればならない。

精神薄弱児は知識・技能の習得が遅く, 一般児童と同 程度の速さで獲得させることが難しい。従って, 将来を 含めて役に立つ指導内容の精選には一般児童以上に慎重 にならざるを得ない。また, 習得した知識・技能の転移 される範囲がせまいのでそれが広く活用できるようにす るためには, 転移に視点がおかれる学習の導入が要請さ れよう。更に, 精神薄弱児は受動的な学習態度を有し, 課題場面でも積極的汇物ごとを処理しょうとしない欠点 があるので，それを矯正していく必要があ万う。以上の 意味から学び方学習の導入は意義が媣い。

本研究ではその内の指導内容については特に追究され ず, 学び方能力の獲得に焦点がしぼられて検討される。 一般に学び方能力の開発には 2 方向の研究が見出され る。1 つは認知論的動㙨づけ研究からの接近である。こ の視点に属する理論として, Hunt $(1963,1965)$ の内発

*国立特殊教育総合研究所
的動機づけ (Intrinsic motivation), Berlyne (1960, 1965，1965）の概念葛藤 (Conceptual conflict), Piaget, Smedslund (1961，1961) の均衡化 (Equilibration), Festinger (1957) の認知的不協和 (Cognitive dissonance) などの諸理論が挙げられる。

波多野と稲垣（1968）はこれらの内発的動機づけ理論 を授業場面に導入して研究している。それに続いて稲垣 (1970)，稲垣と波多野（1971）の一連の研究が報告され ている。これらでは認知的不協和を生起させる手続を導 入することにより，低減情報への知的興味が高まり, 習 得された知識量, その把持, 転移の割合が増加する成果 を見出しており，実際授業への活用の有効性を評価して いる。田口ら（1974）は類似の研究方法で精神薄弱養護 学校中学部の生徒に理科課題を用いて授業を試みた。そ の結果, 自発行動が増加し, 積極的な学習態度が誘発さ れ，模做が生じにくくなるなどが認められ，精神薄弱教 育にも十分に適用できることが確認された。

内発的動機つけ研究を授業へ活用する限界は学習への 課題意識を誘発させる導入段階の扱い方では優れている が，その後をどのような授業スタイルで進めるかは特に 取り扱われていないこともあって指針が得られない点で ある。これについて示唆を与えてくれるのが学び方能力 を獲得させる研究の第 2 の方向である。Bruner (1961) は分析的思考之直観的思考 (Intuitive thinking) とを区 別し, 指導過程では後者に重要な意味を持たせている。 課題解決の導入段階はまさに直観的思考によって達成さ れるものであるが，それが確かであるかどうかの検討は 前者の分析的思考にゆだねられねばならず, 両思考は相 互補足的関係にある。学び方能力はこの両思考の総体で ある。この場合, 直観的思考を効果的にさせる方法の 1 つとして前述の認知論的動機づけの技法が使用されるの である。

Bruner (1961) は学び方能力を開発させる方法として 「発見学習」(Heuristic learning) を提唱する。発見学 習は学習者に発見者と同様の探究過程を追体験させて原 
理や法則を再発見させるならば，獲得された知識や技能 の転移が広くなり, 新しい課題に遭遇した際に, 同様の 探究スタイルで課題が容易に処理できるであろうとする 立場である。広岡と水越（1968）は一般児童にこの方法 を適用して内発的動機を誘発させ, 発見の仕方や探究の スタイルを習得させ，発見・創造する態度・意欲を形成 させて，その妥当性を確認した。

この方法は抽象能力の劣弱な, 既有知識や先行経験の 少ない学習者には適用困難であるといわれる。年齢の下 限は小学校高学年といわれる（広岡と水越 1968）。しか し, 小学校低学年で成功した研究例もない訳ではない (Carin \& Sund 1964, Bruner 1966)。田口らはこれを 全面的に否定するものではないが，適用の限界は指導内 容, 方法との相対的関係で決定される筋合のものであ り, 能力に合致した指導内容で適切に指導されるなら ば, 小学校中学年以下でも精神薄弱児でも適用が可能で あると考える。

本研究は精神薄弱児に基本的内容を素材にして学び方 能力を獲得させる最適な授業スタイルの一形式を構築し てその効果を調べることである。発見学習の導入段階 （観察段階）では前述のように不一致情報を与えて心的 葛藤を生起させ, 課題意識を誘発させる仕方が典型的な 方法として用いられている。本研究でも精神薄弱児に適 用された前研究（田口 1974）の成果に基ゔき, 同様の 方法を導入段階の基本的スタイルとする。これを単に駆 動力 (energizing or activating) として活用するだけに とどめず, 次段階への課題追究的な, 知的な志向つけ機 能 (orientating) として働くように構成する。なお, 精 神薄弱児へ発見学習を導入する場合は学習者の自発性に だけ頼る授業スタイルが成立しにくいので授業者による 積極的な㗢きかけ, 援助が要求される。この条件下で直 観 $\rightarrow$ 予想 $\rightarrow$ 実験 (発見)・検証のプロセスを踏襲させる ことになる。

さて, 本研究では観察段階で不一致情報を与え, それ によって喚起された矛盾や葛藤を課題意識へと高め, 予 想と計画を立てさせて, 実験・検証をとおして基本的内 容（原理）を発見させるスタイルを「発見型授業」と名 付ける。授業スタイルの効果は他のスタイルと比較する ことによって明らかにできるので, そのために仮説的に 構成されたスタイルが「説明型授業」である。この授業 スタイルは観察段階で学習意欲を喚起する駆動力だけに 重点がおかれる調和情報が与えられ, 授業者による課題 への方向づけがなされた後, 基本的内容を知らせるため の演示がなされる。その後, 再度, それを確認させる実 験がもくろまれる。両授業スタイルの決定的な違いは前
者では授業者が学習者に基本的内容を与えず，学習者の 発見に期待をかけるのに対して, 後者では授業者がはじ めの段階で基本的内容を説明し, それの定着化に主眼が おかれる点である。関連した両スタイルの比較研究は精 神薄弱児を対象としたものではないが, 最近, 島田 (1976) が発表している。

本研究で対照型として説明型授業を採用した理由は 1 つには精神薄弱児のような受動的な学習態度に支配さ れ, 自発的な課題追究ができない学習者に対しては, 情 緒的水準の学習意欲を駆り立てて, 授業者が一方的に基 本的内容を与え, 定着化をはかる授業スタイルが採用さ れやすいこと，他の 1 つは精神薄弱児を対象とした授業 でしばしば観察される一般的スタイルが後者のスタイル であることである。

\section{仮 説}

1）知識問題の習得率は授業直後において説明型が，把 持率において発見型が優れるであろう。

2) 転移問題の習得, 把持率では発見型が優れるであろ 5。

3）課題への意欲的な取り組みは発見型に促進されるで あろう。

4）探究的な思考スタイルは発見型に獲得されるであろ 5 。

\section{方法}

被験者：小学校特殊学級に在学している児童であり, 4 学級27名（男子16名, 女子11名）が対象である。ふた りの授業者が発見型と説明型の両スタイルの授業をひ とりは前者から，他のひとりは後者から行ら。そのた め, ひとりの授業者に対して 2 学級ずつが割り当てられ る。両スタイルへの学級の割り当ては学級成員の I. Q (WISC) と生活年齢 (L. A) が等質になるようカウンタ ーバランスされる。授業には TABLE 1 以外に 3 人の児 童が参加したが，ひとりは転校したため，6 か月後の資 料が収集できなかったこと，ふたりは知能が著しく劣っ ており (I. Q, 42 と 45), 知識, 転移問題が十分に聴取 できなかったことのため, 省いて処理した。

授業者および観察者 : 特殊教育経験年数 5 年以上の中 堅男子教師 2 名 $(\mathrm{N} \cdot \mathrm{M}$ 教師) が授業に, 他の 4 名が観察 に当たる。授業者は初対面での緊張関係を最少限度に抑 えるため, 授業前に集団で30分間紹介し合ったり, 話し 合ったりする。また, 観察者は事前テストを行うために 個人別に授業前に10分程度面接する。その外にはどちら も全く接触はない。観察者は授業効果を調べる視点に従 い,テストに関しては個人面接で聴取し，それ以外につ 
TABLE 1 被験群（N授業者群＋M授業者群）の I. Q， L. A の $\overline{\mathrm{X}}$ の比較

\begin{tabular}{|c|c|c|c|c|c|}
\hline & \multicolumn{4}{|c|}{ 発見群 (15名) 説明群 (12名) } & \multirow{2}{*}{$\begin{array}{c}t \text { 值 } \\
d f=25\end{array}$} \\
\hline 観点 & $\overline{\mathrm{X}}$ & $S \cdot D$ & $\overline{\mathrm{X}}$ & $S \cdot D$ & \\
\hline I. Q & 61.6 & 11.78 & 64.3 & 12.70 & $0.56 \mid p>.30$ \\
\hline $\mathrm{L} \cdot \mathrm{A}$ & $\begin{array}{r}\text { מh } \\
134.9\end{array}$ & 10.86 & $\begin{array}{r}\text { का! } \\
128.3\end{array}$ & 14.30 & $1.30 \quad p>.20$ \\
\hline
\end{tabular}

いてはあらかじめ決められた評価基準に従って学習活動 を観察し，チェックする。

指導内容および配当時間：「磁石」（理科）の教材を取り 扱う。第 1 時は「魚つり」を下位題材として磁石は鉄を 引きつけるが，鉄以外は引きつけないことを，第 2 時は 「花と蝶」で磁石と磁石とでは同極は反発し, 異極は吸 引することを, 第 3 時は「雲とロケット」で磁石と磁石 に引きつけられている, 透間のある鉄片との間に別の鉄 を入れると引きつけられた鉄は落ち，鉄以外を入れると 落ちないことを，第 4 時は「高速道路と自動車」で第 3 時までに学習した磁石の性質を用いたおもちゃ作りを指 導する。各授業は30分間で進められる。1 単位時間内の 時間配当は指導過程の区分に従って, 両授業スタイルが 等しくなるようあらかじめ決められている（TABLE 2， FIG. 1)。

授業スタイル：発見型授業と説明型授業の 2 形式で授 業を行う。両者の違いについては問題の項で触れたので 本項では指導計画を例示して説明するとFIG. 1 のように

TABLE 2 指導過程の区分

\begin{tabular}{|c|c|c|c|c|}
\hline 発見型 & $\left(\begin{array}{l}\text { 観 察 } \\
\text { 情報 }\end{array}\right.$ & 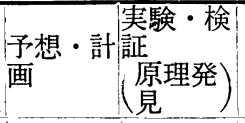 & 生活化 & まとめ \\
\hline 説明型 & $\begin{array}{l}\text { 観 察 } \\
\left(\begin{array}{l}\text { 調和情 } \\
\text { 報 }\end{array}\right)\end{array}$ & 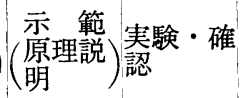 & 生活化 & まとめ \\
\hline
\end{tabular}

なる。これは第 1 時の指導計画である。観察段階では発 見型ははじめに「つれる魚, つれない魚を作ってきたこ とを知らせる」が述べられないので, そのために学習者 に疑問が誘発させやすい。予想・計画段階と示範段階と を比較すると前者は学習者の活動（—ボックス）であ り，後者は授業者の活動（京|ボックス）が中心に進め られる。実験・検証段階と実験・確認段階とは前者が学 習者による原理の発見に終始するのに対して後者は授業 者中心に原理がひとつ，ひとつ確認されていく指導法で ある。生活化とまとめの段階は両授業スタイルとも同一 である (FIG. 1)。

テストと観察基準：（1）知識の獲得とその把持テス
卜 事前, 直後, 事後 ( 1 か月後, 6 か月後) の 4 回にわ たって同一問題で個人別にテストする。問題は授業で用 いた具体物を提示して磁石との関係を問う13問，同じく 絵・カードを提示して問う 3 問, 原理を問う 2 問の計18 問で各問題が 1 点である。

（2）転移テスト 授業で使用しない具体物を提示して 磁石との関係を問う 4 問, 生活場面への適用を問 う 2 問, 計 6 問である。前者の 4 問は知識の獲得・把持テス トに混在させて与えられ, 前調査と同様, 4 回にわたっ てテストされる。各問題 1 点で最高点 6 点である。

（3）意欲の観察基準 自発発言数, 非拘束事態での行 動様式, 宿題の回答数から評価する。自発発言は授業中 に授業者, または他児に対して自発的に発せられた主題 と関係のあることばで意味のあるまとまりを 1 回として 数える。非拘束事態とは毎時間の授業終了直後, 授業者 により「好きなことを自由にしてよいですが，教室から 出ないで遊んでいなさい」という教示で， 5 分間だけ設 けられた自由に遊べる時間帯のことである。評価は磁石 への接触開始時刻と磁石で遊ぶ持続時間, 遊びの内容の 3 視点から行う。段階 3 はすぐに磁石で遊び始め, 長時 間持続する，また，磁石を用いた遊びの内容が優れてい るであり，段階 2 はすぐに磁石で遊び始めるが持続しな い，また，遊び始めは遅いが持続する，段階 1 は遊び始 めが遅く持続しない，段階 0 は磁石で遊ばない であ る。宿題については宿題を回答するように動きかける強 制的な言動は避け，また，回答した場合もなるべく無表 情に受け取り，刺激しないようにする。得点は提出した 回数である。

（4）探究的思考スタイルの観察基準 第 4 時の授業に おける活動を中心に課題意識の明瞭度，作業順序の予定 と実際作業との一致度, 素材の確かめの程度, 分節行動 の量, 素材への接触回数, 模倣回数, 完成品の出来具合 から評価する。課題意識の明瞭度は作業開始直前, 「な にを作りますか」と観察者が個別に質問し，作業課題の 3 つの要素(1)磁石を使って(2)速く走る(3)自動車もしくは おもちゃを作るを正確にいえたかに忍じて，4段階で評 定する。3つともいえた場合が段階 3，2ついえた場合 が段階 $2 ， 1$ ついえた場合が段階 1 ，全部いえなかった 場合が段階 0 である。作業順序の予定と実際作業との一 致度は素材を使用する順序・場所と実際作業で使用され た結果との食い違いから評価する。予定は作業開始直前 に「はじめにどの材料を用いてどこから作りますか。次 はどの材料ですか。次は……」というように質問する。 予定と作業が完全一致した場合が段階 $3 ， 3$ 分の 2 一致 した場合が段階 $2 ， 3$ 分の 1 以下および全くでたらめで 
田口・精神薄弱児における発見型授業と説明型授業との比較研究

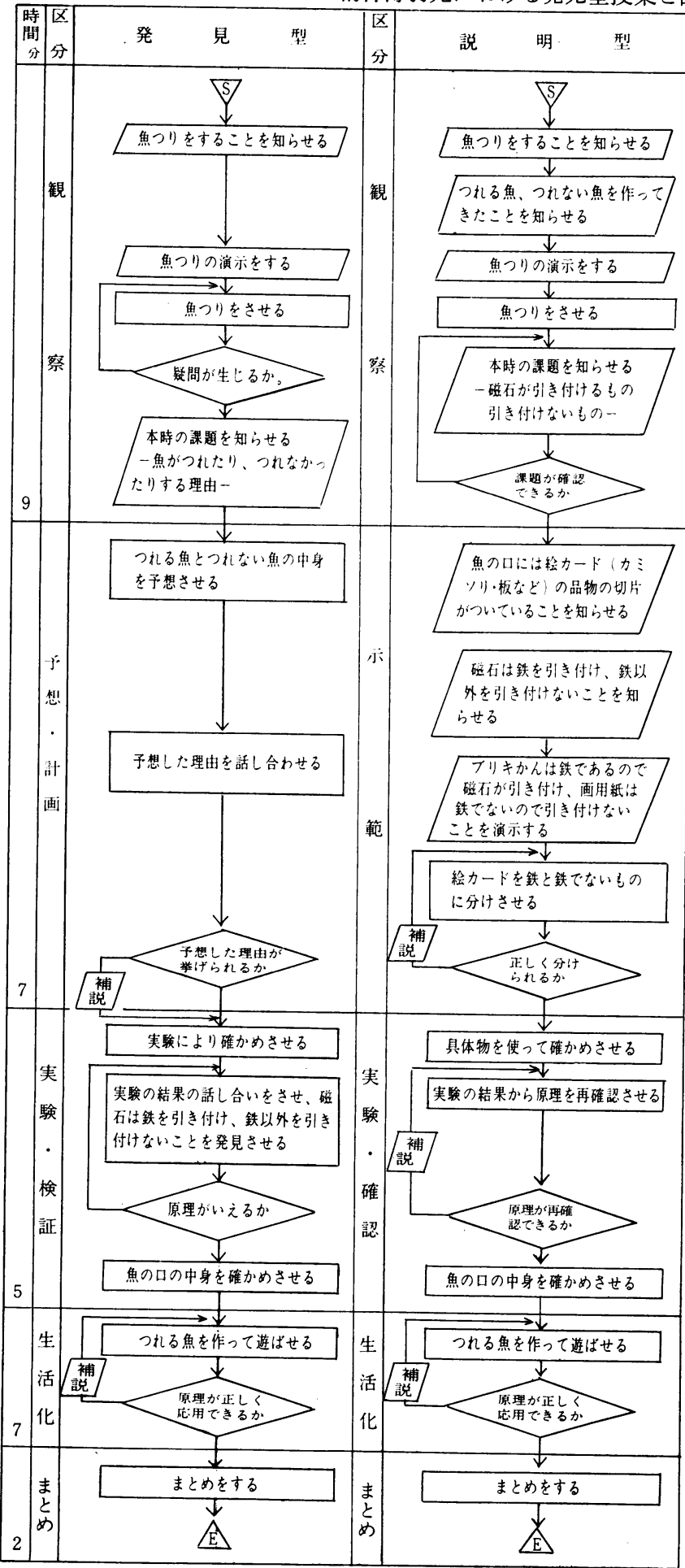

ある場合が段階 1 である。素材の確かめの程 度は作業に取りかかった最初に素材の性質に ついて調べる度合であり，確かめる，確かめ ないの 2 分割で評定する。分節行動の量は下 位作業のまとまりの数である。例えば台紙の 下に磁石をおき，上に鉄片をおいて動かした とすれば，それが 1 つのまとまりのある行動 であるので 1 回と数える。素材への接触回数 は作品が完成するまでに触れた素材数であ り, 延回数である。模倣回数は他児の作品や 行動をみて，それが自分の作品や行動に反映 された数である。完成品の出来具合の評定は 素材の機能が十分に生かされている場合が段 階 3, 部分的にしか生かされていない場合が 段階 2 , 無駄の多い完成品が段階 1 , 未完成 が段階 0 である。

（5）信念の観察基準 第 3 時の授業が終了 した直後, 習得した原理と矛盾する例外的な 事例を個人別に提示し，その理由を聴取す る。評価の基準は段階 3 が原理を固執し例外 的事例を認めない, 段階 2 が例外を認める, 段階 1 が原理の方が間違っていたと述べ修正 する，段階 0 が例外的な事例に疑問を持たず 原理が十分わかっていないのである。

\section{結果}

\section{1 授業条件の比較}

授業の結果を比較する前に両授業スタイル はあらかじめ決められた条件どおりに進めら れたかを検討する。

（1）時間配分 指導過程区分の時間配分は 両授業スタイルの対応する各段階が等しくな るようにもくろまれたが実際授業では学習者 との相互関係で進められる要素が多く, 必ず しも計画どおりに進行したとはいえない。し かし，同一授業スタイルにおける両授業者間 を比較すると，TABLE 3のように差は認め られない。また，授業者別に両授業スタイル を比較しても顕著な違いは認められない。時 間配分についてははじめの計画がほぼ守られ たと解してよい。

（2）授業者の発言内容 授業者の発言は指 導計画を立てる際に大綱が決められ，授業者

FIG. 1 指導計画 第 1 時 磁石「魚つり」 
はそれをカードにして授業に望んだ。しかし，計画どお りに授業が進行しなかったりして，しばしば変更を余儀 なくされた。先ず，両授業者の発言回数を比較すると， 第 3 時までの総計では発見型は $\mathrm{N}$ 授業者が 166, M授業 者が170，説明型はN授業者が 145，M授業者が 135で各 授業スタイル内ではほぼ近似していることがわかる。次 に発言内容について, Amidon \& Hunter (1966) を基 に修正しなおしたカテゴリーにより，第 3 時までを総計 して比較すると，説明型にだけ両授業者間に顕著な差が 認められる（発見型 $\chi^{2}=1.73, d f=7, P>.95,7 \mathrm{~B}$, $8 \mathrm{~A} ， 8 \mathrm{~B}$ は該当発言が少なかったので省いて計算，以下 同じ。説明型 $\left.\chi^{2}=25.14, P<.001\right)$ 。の差は $\mathrm{N}$ 授業者 によるもので説明型が発見型に近似したためである。ち なみに両授業者スタイル間の相関を求めると， N授業者 は, $r=.81 （ \mathrm{~N}=11, p<.02, \quad$ 順位相関, 以下同じ), M授業者は, $r=.44(p>.10)$ であり, N授業者では, 両授業スタイルの接近していることがうかがわれる。し かし授業者別に両授業スタイルを比較するならば，明ら かにN授業者も両授業スタイルの特徴を示す方向（後 述）で違っており，はじめの計画が否定されたものでは ない。N授業者の説明型は発見型と近似してはいるが, 発見型の授業からみると, 相対的に説明型といえるから である。

また，両授業スタイル間をみると， $\mathrm{N}$ 授業者，M授業 者とも顕著な差が認められる（N 授業者 $\chi^{2}=23.26$, $d f=7, p<.005, \mathrm{M}$ 授業者 $\chi^{2}=51.74, p<.001,7 \mathrm{~B}$ $8 \mathrm{~A} ， 8 \mathrm{~B}$ を省いて計算)。発見型に多いカテゴリーは「2」

(N授業者の発見型：説明型， $4.8 \%: 1.4 \%, \mathrm{M}$ 授業者 は $5.7 \%: 0.7 \% ， 7 \mathrm{~B}, 8 \mathrm{~A}, 8 \mathrm{~B}$ を含む全発言数に対する 割合)「6 $\mathrm{B} 」(\mathrm{~N}$ 授業者は $12.6 \%: 2.0 \% ， \mathrm{M}$ 授業者は $11.9 \%: 0 \%)$,「7 A」(N授業者は14.4\%：4.7\%，M授 業者は $17.0 \%: 7.2 \%)$ である。説明型は「 $1 」(\mathrm{~N}$ 授業 者は $1.8 \%$ : 6. $0 \%$ ，M授業者は $11.1 \%: 18.3 \%) ， 「 5 」$ （N授業者は $16.2 \%: 27.3 \% ， M$ 授業者は $12.5 \%$ ：35.0

TABLE 3 時間配分の比較 $\chi^{2}$ 值

$$
d f=4
$$

\begin{tabular}{|c|c|c|c|c|}
\hline & \multicolumn{2}{|c|}{$\mathrm{N}$ 授業者対M授業者 } & \multicolumn{2}{|c|}{ 発見型 対 説明型 } \\
\hline 持限 & 発見 型 & 説 明 型 & $\mathrm{N}$ 授業者 & M授業者 \\
\hline 1 & $\stackrel{3.17}{p>} .50$ & $\stackrel{0.39}{p>} .98$ & $\stackrel{1.62}{p>}>80$ & $\begin{array}{l}1: 19 \\
p>\end{array}$ \\
\hline 2 & $\begin{array}{l}0.79 \\
p>.90\end{array}$ & $\stackrel{1.73}{p>} 70$ & $\stackrel{2.41}{p>} \times 50$ & $\begin{array}{l}1.31 \\
p>\end{array}$ \\
\hline 3 & $\stackrel{2.67}{p>} .50$ & $\begin{array}{l}0.04 \\
p>.99\end{array}$ & $\begin{array}{l}2.09 \\
p>>.70\end{array}$ & $\stackrel{0.32}{p>} .98$ \\
\hline
\end{tabular}

TABLE 4 授業者の発言カテゴリー

\begin{tabular}{|c|c|c|c|c|c|c|c|c|c|c|c|}
\hline 番号 & 1 & 2 & 3 & 4 & 5 & $6 \mathrm{~A}$ & $6 \mathrm{~B}$ & $7 \mathrm{~A}$ & $7 \mathrm{~B}$ & $8 \mathrm{~A}$ & $8 \mathrm{~B}$ \\
\hline $\begin{array}{l}\text { カ } \\
\text { テ } \\
\text { ב゙ } \\
\text { リ } \\
\text { I }\end{array}$ & $\begin{array}{l}\text { 知 } \\
\text { 識 } \\
\text { を } \\
\text { 与 } \\
\text { え } \\
\text { る }\end{array}$ & $\begin{array}{l}\text { ヒ } \\
ン \\
ト \\
\text { を } \\
\text { 与 } \\
\text { 光 } \\
\text { る }\end{array}$ & $\begin{array}{l}\text { 方 } \\
\text { 向 } \\
\text { け } \\
\text { る }\end{array}$ & $\begin{array}{l}\text { 指 } \\
\text { 示 } \\
\text { 委 } \\
\text { る }\end{array}$ & $\begin{array}{l}\text { 確 } \\
\text { 認 } \\
\text { す } \\
\text { る }\end{array}$ & 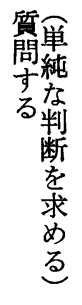 & $\begin{array}{c}\text { 临課 } \\
\text { 閴 } \\
\text { る意 } \\
\text { 識 } \\
\text { を } \\
\text { む } \\
\text { た } \\
\text { せ } \\
\text { る }\end{array}$ & $\begin{array}{l}\text { 考 } \\
\text { 号 } \\
\text { 老 } \\
\text { 受 } \\
\text { 容 } \\
\text { る }\end{array}$ & $\begin{array}{l}\text { 行 } \\
\text { 動 } \\
\text { 亳 } \\
\text { 容 } \\
\text { す } \\
\text { る }\end{array}$ & $\begin{array}{l}\text { 考 } \\
\text { 学 } \\
\text { 売 } \\
\text { 拒 } \\
\text { 否 } \\
\text { す } \\
\text { る }\end{array}$ & $\begin{array}{l}\text { 行 } \\
\text { 動 } \\
\text { を } \\
\text { 拒 } \\
\text { 否 } \\
\text { 寸 } \\
\text { る }\end{array}$ \\
\hline
\end{tabular}

\%) が多いカテゴリーである。これらは両授業スタイル の違いを示寸特徵であり, 最初に計画された発言形式の 違いでもある。

（3）不一致情報に伴なう心的葛藤 観察段階で発見型 は不一致情報を，説明型は調和情報を与えることが意図 されたが，両授業スタイルの指導内容を，できるだけ統 制するようにしたので説明型で十分に調和情報を与える ことができず, 多少，心的暮藤を生じさせる結果となっ た。そこで田口らがもくろんだとおりに発見型により多 く心的葛藤が生起したかを検討する。心的葛藤の評定段 階基準は段階 3 が身をのり出して見る，他児に話しかけ る, 前に出て見る, “あれ，ふしぎだ!”,“おかしい”， “ぼくにもやらせでなどの発言がでる，段階 2 が首を かしげる，゙っと見ている，らなずく，“知っているよ”， 段階 1 が無表情である，何となく見ている，段階 0 がぼ んやりしている，である。両授業スタイルにおける評定 段階の該当人数を比較すると明らかに発見型に強い心的 葛藤が生じている $\left(\chi^{2}=12.55, d f=2 ， 3\right.$ 段階 $\times 2$ 授 業スタイル，段階 3 は該当者がいなかったので省いて計 算, $p<.01 ）$ はじめの計画どおりに発見型に心的葛藤が 生起しているといえよう。

\section{2 知識に関する成績の比較}

(1) 知識の獲得と把持 知識の習得率（直後テスト／ 事前テスト) の平均值は発見型が 1.60 (S. D 0.33), 説 明型が 1.35 (S. D 0.30) であり，発見型の方が傾向程度 ではあるが成績がよい $(t=1.95, d f=25, p<.10)$ 。 た, 把持率の平均値は 1 か月後（1 か月後のテスト/直 後テスト) は発見型が 1.14 (S. D 0.22), 説明型が 0.99 (S.D 0.12)，6 か月後（6 か月後のテスト/直後テス ト）は発見型が 0.95 (S. D 0.27), 説明型が 0.95 (S.D 0.14）である。1 か月後の把持率では発見型が説明型に 比べて顕著に優れている $(t=2.06, d f=25, p<.05)$ 。 6 か月後では両授業スタイルの間に差がない $(t=0)$ 。 知識の平均獲得量についてテスト時点の推移をみると 


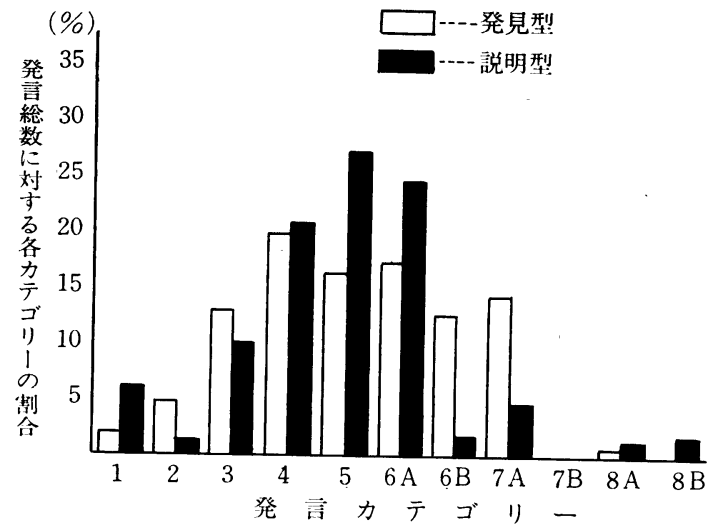

FIG.2 N授業者の発言内容百分率

FIG. 4 のようになる。両授業スタイルと 4 回のテスト成 績との関係を分散分析してみると, 両者の交互作用が有

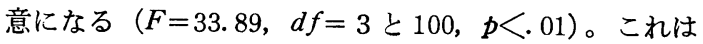
1 つには 1 か月後の事後テストの両授業スタイルの成績 が説明型で事前テストより悪くなっているのに対して, 発見型では反対に良くなっていることによるものと推察 される。

（2）転移 授業值後の転移問題の習得率（值後テスト ／事前テスト）の平均について両授業スタイルを比較す ると発見型が 1.25 (S.D 0.58), 説明型が 1.41 (S.D $0.56)$ で差は認められない $(t=0.70, d f=25, p>.50) 。$ 転移成績の把持率について 1 か月後（1 か月後の事後テ スト／直後テスト）は発見型が 1.24 (S. D 0.32), 説明 型が 1.01 (S. D 0.30)， 6 か月後（6 か月後の事後テス ト/直後テスト) は発見型が 0.85 (S. D 0.40), 説明型 が 0.84 (S.D 0.33) となる。1 か月後だけ発見型の方が 傾向程度ではあるが成績がよい。 $(t=1.82, d f=25, p$ $<.10) 。 6$ か月後は差が認められない $(t=0.07, d f=$ $25, p>.90)$ 。授業直後の転移について田口らは発見型 の方が優れるであろうと仮定したがそのような傾向はな かった。しかし，1 か月後では知識の把持が伸びたのと 同様に転移の成績が発見型に増加している。

\section{3 意欲的な取り組みの比較}

(1) 自発発言数 自発発言の総回数について第 3 時ま での推移をみると両授業スタイル間に顕著な差が見出さ れる $\left(\chi^{2}=6.52, d f=2, p<.05\right.$ 。この差は発見型の発 言数が第 1 時に比べて第 2,3 時の方が多いこと, それ に対して説明型は反対に少なくなり，第 3 時でも第 1 時 を越えるまでにいたっていないことに起因する。

（2）非拘束事態での行動様式 第 1 時, 第 2 時, 第 3 時を比較した場合, 磁石で遊ぶ度合が 1 段階でも上昇し

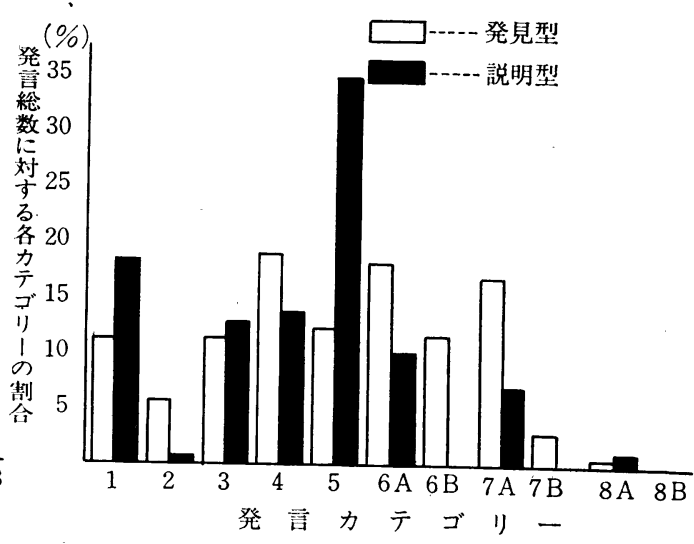

FIG.3 M授業者の発言内容百分率

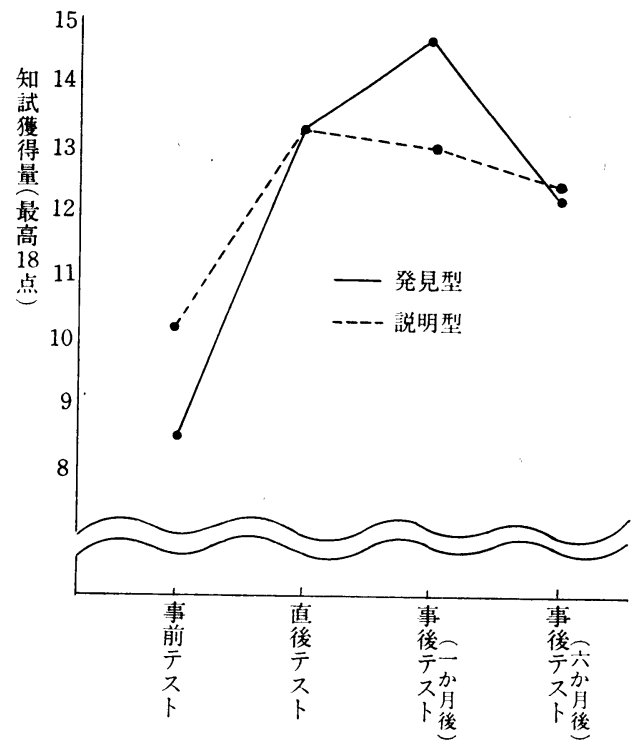

FIG.4 各テスト時点における平均知識獲得量

た学習者, 下降した学習者, また, 変化のなかった学習 者の割合は授業スタイル間に顕著な差が認められる（ $\chi^{2}$ $=6.52, d f=2, p<.05)$ 。これは上昇者, 下降者が発見 型に，変化なしが説明型に多いためであり，必ずしも発 見型に上昇者が多かった効果ではない。

（3）宿題の回答数 第 3 時までの総数を 2 回以上回答 と 1 回以下回答の 2 つに分けて両授業スタイルを比較す ると差は見出せない（ $\left.\chi^{2}=0.20, d f=1, p>.50\right)$ 。ま た, 第 1 時から第 3 時までの回答数の推移（発見型 第 1 時から順に $73.3 \%, 73.3 \%, 60.0 \%$, 説明型 $66.7 \%$, $66.7 \% ， 41.7 \%)$ をみても差があるとはいえない（ $\chi^{2}=$ $0.17, d f=2, p>.90)$ 。

\section{4 探究的な思考スタイルの比較}


（1）課題意識の明瞭度 両授業スタイル間には差は認 められない $\left(\chi^{2}=0.97, d f=2, p>.50\right.$, 段階 0 はひと りもいないため省いて算出)。第 4 時の課題である「自 動車を作る」というねらいは全員がいえている。「磁石 を使って」とか,「速く走る自動車」までくわしく回答 した学習者は発見型で $7.1 \%$, 説明型で $13.3 \%$ と少な い。大多数は「自動車を作る」で十分に回答できたと考 えたのであろう。両授業スタイルの差を検討するには不 適切な質問と考えられる。

(2) 作業順序の予定と実際作業との一致度 両授業ス タイル間に差は見出せない $\left(\chi^{2}=0.13, d f=2, p>\right.$ .90)。

(3) 素材の確かめの程度 発見型の方がわずかではあ るが確かめる学習者が多い $\left(\chi^{2}=1.52, d f=1, p>\right.$ .20)。

(4) 分節行動の量 両授業スタイル間に差はない（ $x^{2}$ $=2.33, d f=2, p>.30,5$ 回以上, $3 \sim 4$ 回, 2 回以 下の 3 分割で計算)。

（5）素材への接触回数 両授業スタイル間に差がある とはいえない（ $\chi^{2}=0.36, d f=1, p>.5,11$ 回以上と 10回以下の 2 分割で計算)。

（6）模倣回数 ひとり当りの平均回数は発見型が 1.87 (S. D 2.19)，説明型が 1.50 (S. D 1.98) である。S.D が非常に大きいので 4 回以上， 1 回から 3 回まで, 模做 なしの 3 段階に分けて両スタイルを比較すると差は認め られない（ $\left.\chi^{2}=0.37, d f=2, p>.80\right) 。$

（7）完成品の成績 段階 3 以上と段階 2 以下の 2 つに 分けて両授業スタイル間を比較すると差は認められない $\left(\chi^{2}=0.09, d f=1, p>.70\right)$ 。末完成の学習者は 4 名で

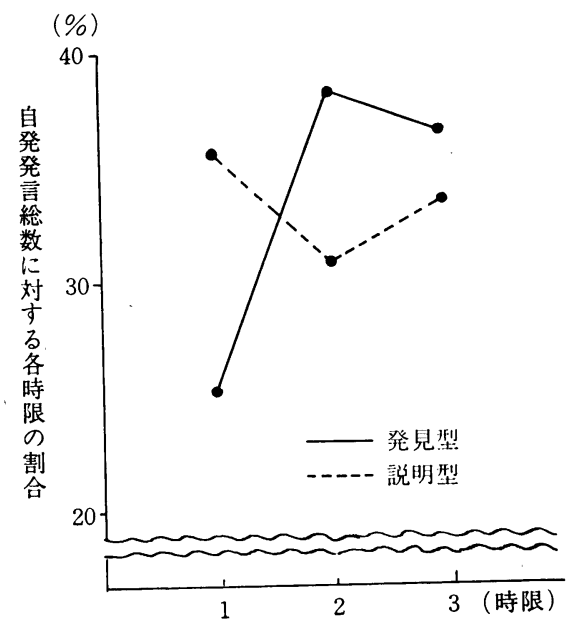

FIG. 5 自発発言の変化
発見型 1 名, 残りの 3 名が説明型である。

以上からみて, 探究的思考スタイルについてはどの観 点も両授業スタイル間に差は認められない。強いて差を 求めれば, 素材を確かめて作業するがわずかではあるが 発見型に,また，未完成な学習者は説明型に多い。

\section{5 信念の比較}

第 2 時の終りに調查した信念を信念あり（段階 3 ， 2）と信念なし（段階 $1 ， 0 ）$ のつに分けて，両授業 スタイル間をみると差は認められない $\left(\chi^{2}=0.52, d f=\right.$ $1, p>$. 30)。

\section{考察}

\section{1 授業者の発言内容}

FIG. 2,3の発言内容について両授業スタイルを比較 すると発見型にはヒントを与える（2），課題意識をも たせる質問 $(6 \mathrm{~B})$, 考え方を受容する $(7 \mathrm{~A})$ が, 説明型 には知識を与える（1），確認する（5）が多発してい る。以上のカテゴリーは両授業スタイルの特徵を示して いるものと思われる。前者の「2」と後者の「1」は情報 の提供方法の違いを示しており，一方は学習者から誘い 出す, 他方は授業者が与える違いである。質問のうち, $\lceil 6 \mathrm{~B} 」 は$ 発見型に著しい。他の単純な判断を求める質問 (6A) はN, M両授業者で反対の傾向であり, どちらが多 いともいえない。しかし，M授業者の割合を吟味すると 両質問カテゴリーとも発見型に比べて説明型が顕著に少 ない(全質問数の全発言数に対する割合，発見型が 30.1

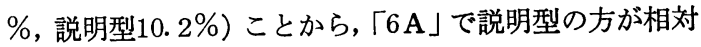
的に低くなったとも推察され， $\mathrm{N}$ 授業者にみられるよう な「6A」が説明型に多いのが一般的な傾向と思われる。 以上から「6A」は説明型に，「6B」は発見型に多発する 質問傾向といえよう。「5」は情報を与えて, それが理解 できたかどうかを確かめるカテゴリーであり，説明型の 典型と思われる。発見型ではヒントを与えて, 学習者に 思考させ, それを発表させてその発言を受容するという スタイルになるので「5」は少なくなる傾向にある。

\section{2 学び方能力}

学び方能力は獲得された知識や技能, それを生活に活 用する意欲, 転移能力および探究的な思考スタイルの 4 測面の総合としてとらえられる。Cronbach (1966) は発 見学習の評価基準として12項目を挙げているが，それは 以上の 4 側面を更に細かく分割した項目といえる。本研 究の 4 領域にわたる評価観点は部分的に Cronbach に従 っている。

知識の習得率は発見型, 説明型間に差は見出されな い。仮説では説明型は原理をひとつひとつ指導し, それ 
を確認しながら進める仕方であるので，学習者から原理 を引き出し，それを容認する間接的な進め方である発見 型に比べて成績がよくなると予想したのである。しか し,これは確認されなかった。この結果の示唆するもの は発見型でも十分に知識を習得させることができるとい うことである。

把持率は 1 か月後の事後テストにおいて発見型が有意 味に成績がよい。これは仮説のとおりである。その理由 として挙げられるのは第 1 に原理を自分自身で発見させ たことが情緒的に銘記させやすくした点である (Bruner 1961）。第 2 に知的興味が向上して日常生活にまで追究 意欲が持続し, 磁石で遊んだり, 磁石が使用されている 器具などへ関心が向き, 自然に再学習された点がうかが える。生活空間で磁石の使用されているか所を聴取した ところ, 発見型にだけ, 冷蔵庫のとびらとか, カバンの ふたとか, また, ラジオ, テレビなどに使用されている と答えた学習者がみられる。直後テストで誤答であり, 1 か月後の事後テストで正答に変った解答が発見型に多 く見出される点は特記されてよかろう。3問題以上がそ れに該当する学習者は発見型 7 名, 説明型 1 名である。 その内, 直前, 直後テストで失敗し, 1 か月後のテスト で成功した解答を 3 問題以上有する学習者は 6 名があ り, 発見型が 5 名を占める。この 5 名は直後テストのと き，「磁石が欲しいですか，それはできるだけ早く欲し いですか」の質問に共通して肯定的な回答をしている。 そして，2名はそれをすぐに果たしているし，3名は 1 週間おいて同様に果たしている。

6 か月後の事後テストでは授業スタイルの違いの効果 は消失している。3 時間の授業効果が 6 か月後まで持続 しなかったためであろう。まだその記憶が残存してお り, 知的興味を保持している間に更に関連教材を与えて いくことが次の学習を効果的に進める駆動力になると思 われる。

転移問題の比率は直後のテストにおいても，1 か月後, 6 か月後のテストにおいても発見型と説明型との間に差 違は認められない。これは田口らの仮説に相反する結果 である。その理由として挙げられるのは知識問題と転移 問題の内容があまりに類似していたために両問題間に差 が生じにくくなったものと推察される。両問題は授業で 直接使用する素材, 使用しない素材の違いだけで構成さ れている。ちなみに直後テストにおける両問題間の成績 の相関を求めるならば $r=.54(d f=25, p<.01$, 錯差 積相関係数）となり，近似していることがうかがえる。

本研究では探究的思考スタイルは全くといってよいほ ど習得されていない。この理由として先ず， 3 時限とい
う授業時間の範囲内では効果をあげることが難し過ぎた のではないかといら点が指摘できる。この点に関して は，一般児童にも同様の手続で授業を行い, その効果を 確かめる必要があろう。次に精神薄弱児にはこのような 思考スタイルの習得が本来, 不得手であるという久陥が あるために効果があげられにくかったのではないかとい う点が指摘できる。元来, このような思考スタイルは精 神薄弱児にとって劣弱であるといわれている (Пинский 1968）。従って，その習得も非常に難しいと思われる。 本研究ではこのような欠陥を取り除く有効な方法を開発 することがひとつのねらいであったが，その点は仮説ど おりにはいかなかった。

その他にも差を生じにくくさせた理由が見出せる。そ れは第 4 時の作業内容が第 3 時までに学習された知識や 技能のすべてを応用する課題であり，それに対して第 3 時までの成績（直後テストの平均正答率, 発見型 72.2, S. D 15.42，説明型，73.3，S. D 17.78）が不完全で課 題に耐えられるほど習得されていなかったために，仮説 一検証的でなく，試行錯誤的に追究させてしまったこと に起因するのではないかと思われる。第 4 時の課題をや さしくするか，または指導内容が十分に獲得されるまで 時間を延長して指導する方法を採用すべきであったので あろう。もう 1 つは両授業スタイルの条件差以上に個人 差の要因が影響を及ぼしたためとも推察される。これは 項を改めて考察する。

\section{3 授業条件に影響を与える他の要困}

両授業スタイルの条件差に与える他の影響要因として 学級差と個人差の 2 つが挙げられる。学級差は担任教師 の日常のしつけによって決定される要因である。例え ば，授業中，自由に発言することを封じる教師や，ま た, しばしば, 宿題を課し, それを提出するよう強制す る教師がいる。このようなしつけに基づく行動様式は本 研究のような数回の授業だけで容易に変えられるもので はない。本研究では複数学級の平均という手続でそのし つけの差を消去することを意図したがそれが十分に達成 されたとはいえず，その差が両授業スタイルの条件差に 影響を与えたとも考えられる。

このようなしつけの影響を受けやすい評価観点は意欲 に関するカテゴリーで, 自発発言, 非拘束事態の活動, 宿題などである。自発発言には前述のように発問に対す る応答という形式を重視して授業を進める教師が見出さ れ, 学習者もその形式に慣らされている場合がある。そ こで第 1 時の授業について, 応答発言に対する自発発言 の割合の学級平均を求めてみると, $\mathrm{N}$ 学級（発見型授 業を行う) は 0.30 (S. D 0.10), A 学級 (発見型) は 1.33 
(S. D 0.48), K学級 (説明型) は 1.48 (S. D 1.26), T 学級 (説明型) は 1.73 (S.D 1.80) となり，N学級が他 の学級に比べて自発発言をほとんど認めていないことが らかがえる。そのために, N学級では発言を自由にする ことが促されると, がぜん, その割合が増え, 第 2 時で は 3.0 倍にまで増加している。

非拘束事態の活動は授業が終った直後, 授業で取り扱 った素材をいかに活用して遊んだかである。第 1 時の授 業終了後をみると， N学級は全員が段階 0 か 1 に集中, それに対して，T学級は段階 3 か 4 に，A学級も 1 名の 段階 1 を除いて段階 3 に集中している。K学級だけが全 段階に散らばっている。N学級は教卓のところへ出て, 授業で用いた素材で遊ぶことを平常は禁止しているし， T，A学級は黙認していることがうかがえる。このよう な実態のため， $\mathrm{T}, \mathrm{A}$ 学級では第 1 時から段階 $2 ， 3$ で 天井つきであった学習者が多く, それ以上, 好転するこ とを期待するのが難しかったし，また， N学級でははじ めに段階 0,1 であった学習者が多かったので, 非拘束 事態で「前にでて遊んでもよいよ」と強調しなければな らない状態であった。

宿題は第 1 時の回答数の割合をみると $\mathrm{N}$ 学級が 87.5 \%, A学級が $57.1 \%$ ， K学級が $80.0 \%$ ， T学級が 57.1 \%となる。非強制事態での宿題であった点を考慮してど の学級も半数以上が回答したことからすると, 平常から のしつけがゆきとどいていたということではなかろう か。そのために差がでにくかったのであろう。

学習者の個人差のらち, 成績一比較的に影響を及ぼす 要因は知能である。授業スタイル間でこの要因はあらか じめカウンターバランスしたのであるから結果の資料の 分析では無視されるべきであろらが知能差が授業スタイ ル差以上に影響を与えた場合もありえると思われるので 条件差の生じにくかった探究的思考スタイルについては 特に知能との相関関係を検討してみる必要があろう。 I. Q を 69 以上, $68 \sim 55,54$ 以下の 3 群，各群 9 名ずつ に分け，それと下位観察項目の評定段階との間の $\chi^{2}$ 値, 連関係数 ( $C$ 係数) を求めてみる。

課題意識の明瞭度, 作業順序の予定と実際作業との一 致度は I. Q との間に相関は見出せない（前者は $C=.26$, $\chi^{2}=1.96, d f=4, p>.70$, 後者は $C=.40, \chi^{2}=5.19$, $d f=4, p>.20)$ 。また, 分節行動の量, 完成品の成績 もそれぞれ相関がない（前者は $C=.31, \chi^{2}=2.80, d f$ $=4, p>.50$, 後者は $C=.36, \chi^{2}=3.99, d f=2, p>$ .30)。模倣については相関が多少ある $\left(C=.50, \chi^{2}=\right.$ $8.89, d f=4, p<.10)$ 。これは IQ が低いほど，模倣 回数が多いという方向性である。模倣が授業スタイル間
に差のなかったのは知能の個人差の方が大きかったため であろうと思われる。

以上から, 本研究に関する限りでは自発発言数, 非拘 束事態での行動様式は学級差と, 模做は知能差と関係が 深い。これらは授業スタイルの条件差をみる観察項目と しては他の要因が加味されるので適当ではないと思われ る。宿題は第 1 時では 4 学級とも差は少なかったが， 3 時間程度の授業ではその条件差の効果が現われにくいも のであろう。

\section{要 約}

現在および将来の社会生活を過ごすために「学び方能 力」の育成は必須である。この能力は, 特に Bruner が 提唱した「発見学習」によって獲得させることができ る。発見学習とは基本的内容を観察一予想一実験（発 見)・検証のプロセスで学習者自身に発見させる仕方で ある。

この授業スタイルは抽象能力や既有知識, 先行経験の そしい学習者には適用が難しいとされている。しかし， 授業は指導内容, 方法との相対的関係で成立するもので あるから, 能力に合った指導内容を設定して, 学習者の 自発性だけに頼らず，授業者が積極的に働きかけたり， 援助したりするならば, これらの学習者にも必ずしも適 用が不可能ではないと思われる。

本研究はこのような観点から構築された発見型授業が 精神薄弱児に適用可能かどうかを検討するものである。 対比される授業スタイルとして説明型授業を構成する。 これは観察一示範一実験・確認のプロセスで進められる 授業者主導型スタイルである。

被験者は小学校特殊学級 27 名で, I. Q と L. A が釣合わ された 2 グループに分けられ, 発見型と説明型授業を受 ける。授業者は 2 名で始めにひとりは 1 グループの半数 に発見型授業を，もうひとりは他のグループの半数に説 明型授業を次に残りの半数にも5 1 つの型の授業をそれ ぞれ行う。指導内容は理科教材で「磁石」を取扱い，第 3 時までを 2 授業スタイルにより, 第 4 時は共通の授業 スタイルによりおもちゃ作りの作業課題をする。評価に 関しては 4 名が授業の事前, 直後, 事後（ 1 か月後, 6 か月後）にわたって知識，転移テストを聴取，授業中の 意欲, 探究的思考スタイルを評定する。

結果は次のとおりである。

(1) 授業者の発言内容は両授業スタイルの特徴を示す 方向で異なる。発見型に多いカテゴリーは, ヒントを与 える, 課題意識を持たせる質問, 考え方を受容する,で あり，説明型に多いカテゴリーは，知識を与える，確認 
する,である。

（2）知識問題の習得率（直後テスト/事前テスト）で は両授業スタイル間に差が見出されない。しかし， 1 か 月後の把持率（1 か月後の事前テスト／直後テスト）で は発見型が顕著によい。その効果は 6 か月後では消失し ている。

（3）転移問題の習得率（直後テスト／事前テスト）は 両授業スタイル間に差はない。これは転移問題と知識問 題が類似していたためである。

（4）自発発言数は第 1 時より, 第 2,3 時で発見型が 増加している。

（5）第 4 時の授業中に測定された探究的思考スタイル は種々の観点から分析されたが, どれも差は見出せな い。

（6）習得された知識と矛盾する事例を観察させてその 反応から信念を分析したところ，両授業スタイル間に差 は見出されない。

\section{文献}

Amidon, E. \& Hunter, E. 1966 Improving teaching The anaiysis of classroom verbal interaction. Holt, Rinehart \& Winston.

Berlyne, D. E. 1960 Conflict, arousal, and curiosity. McGraw-Hill.

Berlyne, D. E. 1965 Structure and direction in thinking. Wiley \& Son.

Berlyne, D. E. 1965 Curiosity and education. In J. D. Krumboltz (ed.) Learning and the educational process. Rand McNally.

Bruner, J. S. 1961 The process of education. Oxford University Press.

Bruner, J. S. 1961 The act of discovery. Harvard educ. Rev., 31, 21-32.

Bruner, J. S. 1966 Toward a theory of instrvction. Harvard University Press.

Carin, A. \& Sund, R. B. 1964 Teaching science through discovery. Charles E. Merrill Books.

Cronbach, L. J. 1966 The logic of experiments on discovery. In Shulman, L. S. \& Keislar, E. R. (eds.) Learning by discovery. A critical app- raisal. Rand McNally.

Festinger, L. 1957 A theory of cognitive dissonance. Evanston : Row, Peterson.

広岡亮蔵・水越敏行 1968 発見学習 (東洋他編 学習 心理学ハンドブック）金子書房

Hunt, J. McV. 1963 Motivation inherent in information processing and action. In O. J. Harvey (ed. ) Motivation and social interaction. Cognitive determinants. Ronald Press.

Hunt, J. McV. 1965 Intrinsic motivation and its role in psychological development. In D. Levine (ed. ) Nebraska symposium on motivation. University of Nebraska press.

稲垣佳世子・波多野誼余夫 1968 認知的観察における 内発的動機づけ 教心研, 16, 4, 191-202

稲垣佳世子 1970 情報の受容および収集に及ぼす認知 的動機づけの効果 教心研, 18, 1, 14-25

稲垣佳世子・波多野誼余夫 1971 事例の新奇性にもと うく認知的動機うけけ効果 教心研, $19,1,1-12$

ピンスキー（駒林邦男訳）1968 ちえ遅れの子の学習活 動 明治図書

島田昌幸・岡田立美・黒木敬一 1976 法則学習におけ る関数の学力と指導類型の効果 日教心第18回総会 発表論文集, 558-559

Smedslund, J. 1961 The acquisition of conservation of substance and weight in children. V. Practice in conflict situations without external reinforcement. Scand. J. Psychol., 2, 156-160

Smedslund, J. 1961 The acquisition of conservation of substance and weight in children. VI. Practice on continuous vs. discontinuous material in problem situations without external reinforcement. Scand. J. Psychol., 2, 203-210

田口則良 1974 精神遅帯児の概念学習における認知的 動機づけ 日教心第16回総会発表論文集，610-611 〈付記〉

本研究は国立特殊教育総合研究所昭和 50 年度長期研修 生 和田甫, 錦織定, 毛利稔宏, 秋山浩氏の協力によっ て成立したものである。

（1977年 2 月 12 日受稿） 


\section{ABSTRACT \\ A COMPARATIVE STUDY BETWEEN HEURISTIC AND EXPLANATIVE INSTRUCTIONS IN MENTALLY RETARDED CHILDREN \\ by

\author{
Noriyoshi Taguchi
}

Heuristic instruction is a style of educational technique to lead pupils to discover the basic contents of instruction by means of a process of hypothesis and verification.

The purposes of the proposed study were to ascertain whether or no this style could be applicable to mentally retarded pupils. As a contrasted style with the above technique, an explanative instruction was induced in which the basic contents were to be initiatively shown to the pupils by the instructor.

Twenty-seven pupils, who belonged to special classes for the mentally retarded, participated as subjects for this project and were divided into two groups of the heuristic and explanative instructions. Two male instructors ( $N$, and $M$, we call them temporarily) took part in both styles of this project, that is, they guided half each group.

The subject of the instructions, treated in four sessions lasting almost four hours, was "The property of magnet" categorized in science. Four staffmembers were employed to ask the pupils learning and application questions before and after each instruction (Pre-instruction test, Post-instruction test, Follow-up test $\cdots 1$ month later), and to rate motivated activities and thinking style of inquiry which were thought to be in connection with the instructions.

The results were as follows.

1. There was a meaningful difference between the two instructors in connection with the contents of their speech $\left(\mathrm{N}\right.$-instructor : $\chi^{2}=33.06, d f=7, \quad p<$ .001, M-instructor : $\left.\chi^{2}=75.50, d f=7, \quad p<.001\right)$.

2. The ratio of Post-instruction test to Pre-instruction test on the learning questions was not discriminated between the two types $(t=1.95, d f=25$, $p<.10)$, but in the ratio of Follow-up test to Postinstruction test, the two types were significantly different $(t=2.06, d f=25, p<.05)$, the heuristic style showing better figures.

3. Through all three sessions of the application questions, the discrepancy of the two types was not found.

4. As for the evaluation on the motivated activities and the thinking style of inquiry, there was little difference between the two types of instruction. 